\title{
OUTWARD INVESTMENT TO CHINA AND LOCAL INNOVATION OF TAIWANESE MANUFACTURING FIRMS*
}

\author{
By CHIH-HAI YANG †, YI-YIN WU $\ddagger$ and HUI-LIN LIN§ \\ $\uparrow$ National Central University $\ddagger$ National Chengchi University \\ $\S$ National Taiwan University
}

\begin{abstract}
Does outward investment induce more domestic innovation or simply move local innovative efforts to foreign plants? This question is topical and relevant to Taiwan in view of its large share of outward investment concentrated in China and the special political relationship between the two sides of the Taiwan Strait. The purpose of this paper is to examine the effect of outward investment in China on domestic innovative activity in Taiwan. Overall, this study finds that a positive relationship exists between outward investment and innovation in terms of R\&D intensity and patents, implying that investing in China is part of a global resource allocation strategy of Taiwanese multinational enterprises to allocate production in China and pay more attention to innovative activity in their domestic plants. Moreover, the deregulation of the policy regarding investing in China in 2001 has induced an upsurge in investment in China, although it does not seem to have brought about an outflow of technologies.

JEL Classification Numbers: F21, F23, O32.
\end{abstract}

\section{Introduction}

Engaging in production abroad is a way of expanding foreign market share and has also been widely adopted as a strategy to slow the decline in a firm's competitiveness through the manufacture of goods in low-wage countries. Therefore, the establishment of foreign production affiliates is often referred to as a natural process of internationalization. There have been many theoretical arguments explaining the motivation underlying foreign direct investment (FDI). ${ }^{1}$ From the firm's perspective, moving production overseas is aimed at exploiting firm-specific advantages, ownership advantages, or internalization advantages (Dunning, 1988, 1998), and can therefore contribute to a firm's growth (Chen and Ku, 2000) and productivity (Suh, 2005). However, there is growing concern over the effects of FDI on the domestic economy.

Among FDI's potential effects on the domestic economy, whether or not and how FDI impacts domestic innovation has attracted the attention of both economists and policymakers. Empirical studies on the determinants of FDI have found that acquiring and accessing advanced technologies in the host country is one of a firm's major purposes

* The authors would like to thank Jin-Tan Liu, Jin-Long Liu, Meng-Wen Tsou, two anonymous referees, and the co-editor Kazuo Ogawa for their helpful comments and suggestions on an earlier version of this paper. Chih-Hai Yang acknowledges the financial support of the Council for Economic Planning and Development, Executive Yuan (96-036-206). Chih-Hai Yang and Hui-Lin Lin also acknowledge the financial support of the Center for China Studies of National Taiwan University. Any opinions expressed are those of the authors and not those of the Council for Economic Planning and Development. The usual disclaimer applies.

1 In this article, the term FDI denotes outward FDI rather than inward FDI. 
(e.g. Kogut and Chang, 1991; Walz, 1997; Co and List, 2004), implying that FDI may be positively related to a multinational enterprise's (MNE's) home R\&D. However, from a macro-perspective, international investment serves as an important channel for international knowledge spillovers whereby firms in the host country can acquire advanced technologies and management knowledge from invested MNE. If MNE transfer technologies to foreign affiliates, reallocate $R \& D$ departments to foreign affiliates, and then reduce domestic $\mathrm{R} \& \mathrm{D}$, this will result in an erosion of the technological advantages of the home country or technology outflows. Will FDI affect domestic innovative activity and if so, how? One practical way is to examine what happens to a firm's innovative activity after it engages in overseas investment. Although the real effect of FDI on domestic innovation is both important and of particular interest, only a few studies have examined this question and numerous ambiguities and uncertainties remain, suggesting the need for further empirical studies.

The topic addressed in this paper is especially important and relevant to Taiwan owing to the following specific features of the country's increased FDI. As a result of the similarities in language and culture, almost half of Taiwan's FDI has been concentrated in China since the late 1990s. When the regulation regarding FDI in China by the electronics industry was relaxed in 2001, it was mainly electronics firms that contributed to the ongoing increase in the amount and share of FDI in China. By drawing on an original questionnaire survey and firm-level interviews, Chen (2004) pointed out that a tendency existed among Taiwanese IT firms to engage in cross-Strait R\&D, in order to meet the needs of the global production network. The Ministry of Economic Affairs (2007) has found that the ratio of R\&D expenditure allocated to affiliates of Taiwanese MNE in China exhibits an upward trend, suggesting that MNE are devoting more innovative activity to local market-oriented refinement in China or are attempting to utilize local R\&D human resources that are low-cost and high in quality as they develop new products or technologies. From the perspective of firms' globalization strategies, the international allocation of $\mathrm{R} \& \mathrm{D}$ activity helps them to maintain their competitiveness by allocating resources efficiently. However, due to the special political relationship between Taiwan and China, this phenomenon has given rise to serious concerns as to whether technological knowledge outflows to China along with FDI are eroding Taiwan's technological advantages, especially in regard to high-tech industry technologies.

This paper aims to analyze the effect of FDI in China on domestic innovative activity in Taiwan. First, we study the impacts of FDI on the domestic R\&D investment level and $\mathrm{R} \& \mathrm{D}$ productivity in terms of patent applications. Second, by exploiting stock-listed firms and their regulated FDI in China, this study adopts the generalized method of moments (GMM) approach to take into account both the endogenous causality between FDI and innovations and the impact of deregulation on the FDI-innovation nexus, providing a consistent estimate of the effect of FDI in China on domestic innovations. Third, we compare the potential differences in the effects of FDI in China on domestic innovations between manufacturing firms and electronics firms. This examination provides insightful implications concerning the deregulation of FDI in China for electronics firms from Taiwan.

The remainder of this paper is organized as follows. In the next section we provide a summary review of the theoretical and empirical literature on the potential impact of FDI on domestic innovation. We then present a brief overview of Taiwan's FDI in China and regulations concerning FDI for large corporations. Section 3 describes the dataset utilized in the empirical analysis and provides some descriptive evidence of China's FDI. Section 
4 discusses the empirical specifications and econometric methods adopted. The results for the effects of FDI in China on domestic R\&D investments and R\&D productivity are displayed and discussed in Section 5. The final section presents the study's conclusions and policy implications.

\section{Literature review and Taiwan's outward FDI}

\subsection{Literature review}

The theoretical literature discussing the impact of FDI on domestic innovation has been ever-increasing over the past decade. However, the predicted innovation effect of FDI leads to some contrasting results in the literature, depending on the assumptions of the conditions between the host and guest countries. By incorporating FDI in a general equilibrium model with endogenous technological change or starting from a twocountry imperfect competition model to simultaneously consider decisions regarding R\&D and FDI, Walz (1997) and Petit and Sanna-Randaccio (1998, 2000) reach a similar conclusion that there is a positive relationship between multinational expansion and $R \& D$ investment when the investing and receiving countries have similar levels of technological capability. Moreover, they indicate that firms should acquire specific knowledge through FDI and R\&D investment in more developed countries. In adopting the model of Cohen and Klepper (1996) to derive the domestic and foreign R\&D investment function, the theoretical model by Belderbos et al. (2006) predicts that the respective shares of the foreign and domestic $R \& D$ investments of MNE depend on the relative technological opportunities and relative demand conditions. If the destination country has more technological opportunities and a large market, then MNE may reallocate more R\&D investment to their foreign affiliates, resulting in a decrease in the parent firms' innovative activities.

Unlike the above-mentioned predictions drawn from investing in developed countries, there is another issue that arises for the FDI-innovation nexus when firms concentrate their FDI in the low-cost country. By using a three-stage game, Chen and Hsu (2003) find that the impact of FDI on a firm's domestic R\&D is ambiguous, depending on the level of the technological spillover. To examine whether investing in the lower-cost country negatively affects the MNE's R\&D investment in the source country, Tsai and Chiou (2007) argue that the lower the host country's wage or the larger the market's size, the more likely it is that the MNE's R\&D investment will decrease due to outward direct investment when labour and technology are substitute inputs.

Based on the theoretical arguments, while investing in developed countries is helpful for learning advanced technologies and promoting domestic innovative activity, it may also, by means of the following mechanisms, lead to a decrease in the parent firms' R\&D efforts, especially in the case of FDI in low-wage countries. The first such mechanism concerns the local market-oriented R\&D. As pointed out by Belderbos et al. (2006) and Tsai and Chiou (2007), the large market size, demand, and greater technological opportunities in the host country, such as China, induce MNE to engage in more adaptive R\&D, which is geared toward developing new products to meet the needs of the local market. When the MNE's resources devoted to $R \& D$ are limited, the increase in foreign $R \& D$ will reduce the parent firms' R\&D. The second mechanism relates to the resourceoriented R\&D in the host countries. If the host developing country has R\&D human resources that are both high-quality and low-cost, as well as policy measures to encourage 
innovative activity, MNE will reallocate their innovative activity from the parent country to the investing country. This argument is relevant to FDI directed toward China. In actual fact, China became the third most important offshore R\&D location for MNE in 2004 (United Nations, 2005). This development in R\&D internationalization suggests that China can attract not only physical investment, but also the overseas R\&D of MNE, leading to a possible decrease in the MNE's domestic R\&D. Moreover, FDI in developing countries enables MNE to take advantage of cost saving and extends the life cycle of their products. It also reduces the need for MNE to invest in R\&D in the home country.

Empirical studies on the effect of FDI on domestic innovation also give rise to mixed results. Lispey (1994) first examines the potential impact of FDI on domestic R\&D and finds that American firms with a higher ratio of overseas production tend to upgrade their $\mathrm{R} \& \mathrm{D}$ activities at home when they move the low-technological production to low-cost countries. There is a positive relationship between FDI and domestic innovation. A similar result for a positive FDI-domestic innovation nexus is also found in Lin and Yeh (2005) in the case of Taiwan's electronics industry.

Fors (1997) indicates that R\&D undertaken by firms in the home country is used as an input in both the home and foreign plants of the MNE, suggesting that technology is transferred to the foreign plants. Slaughter's (2000) study on US-headquartered MNE shows that the transfer of production stages from US parents to foreign affiliates has a significant impact on within-industry shifts in the USA from relatively labour-intensive activities toward those that are more skilled, implying that FDI exerts no significant impact on domestic R\&D. Head and Ries (2002) investigated the influence of offshore production by Japanese multinationals on domestic skill intensity and found that the effect of FDI on domestic skill intensity depends on the technology level of the host country. Based on Japanese MNE's R\&D expenditures in the USA and Japan, Belderbos et al. (2006) distinguished R\&D into research and development activities and found that research expenditure responds to relative technological opportunity, but development expenditures do not. The estimated coefficients are consistent with a relatively high elasticity between foreign and domestic research activities.

\subsection{Overview of Taiwan's FDI in China and its policy}

There was little and only sporadic FDI engaged in by Taiwanese firms before the mid-1980s. Due to the enormous changes in the industrial environment-such as those in relation to environmental protection, increasing land and labour costs, and a violent fluctuation in Taiwan's local currency - that emerged as major issues from the late 1980s, many labour-intensive firms began to move their production lines overseas. Accompanied by foreign exchange deregulation, the amount of FDI surged substantially. According to the official statistics compiled by the Ministry of Economic Affairs in Taiwan (see Table 1), the magnitude of FDI increased from \$US1.830bn in 1991 to \$US11.957bn in 2006.

It can clearly be seen that China emerged on the FDI map and gradually became the most popular destination for Taiwanese investors starting in the early 1990s. The value of FDI in China exhibits a steadily increasing trend with unusual spikes in 1993 and 1997, with galloping increases in 2002 and 2003. Compared with other countries, China is a unique destination for Taiwanese investors. Due to historical, political, as well as market factors, China is a very attractive and highly preferred FDI destination for many Taiwanese firms, even though there are many potential investment risks. 
TABLE 1

Taiwan's outward foreign direct investment by locations

\begin{tabular}{rrrrrrrrr}
\hline \hline & \multicolumn{1}{c}{ Total } & USA & Japan & Hong Kong & ASEAN & Europe & Others & China \\
\hline 1991 & 1,830 & 298 & 3 & 200 & 720 & 60 & 375 & 174 \\
1992 & 1,134 & 193 & 5 & 54 & 309 & 46 & 279 & 247 \\
1993 & 4,829 & 529 & 63 & 162 & 434 & 256 & 217 & $\mathbf{3 , 1 6 8}$ \\
1994 & 2,579 & 144 & 23 & 127 & 398 & 22 & 903 & 962 \\
1995 & 2,450 & 248 & 9 & 100 & 326 & 60 & 614 & 1,093 \\
1996 & 3,394 & 271 & 7 & 60 & 587 & 12 & 1,228 & 1,229 \\
1997 & 7,228 & 547 & 32 & 142 & 641 & 59 & 1,473 & $\mathbf{4 , 3 3 4}$ \\
1998 & 5,331 & 599 & 30 & 69 & 477 & 34 & 2,088 & 2,035 \\
1999 & 4,522 & 445 & 122 & 100 & 522 & 61 & 2,018 & 1,253 \\
2000 & 7,684 & 862 & 312 & 48 & 389 & 37 & 3,429 & 2,607 \\
2001 & 7,176 & 1093 & 169 & 95 & 523 & 46 & 2,466 & 2,784 \\
2002 & 10,093 & 578 & 24 & 167 & 211 & 123 & 2,268 & $\mathbf{6 , 7 2 3}$ \\
2003 & 11,668 & 467 & 100 & 641 & 298 & 77 & 2,385 & $\mathbf{7 , 6 9 9}$ \\
2004 & 10,323 & 557 & 149 & 140 & 966 & 62 & 1,508 & 6,941 \\
2005 & 8,454 & 315 & 43 & 108 & 264 & 299 & 1,420 & 6,007 \\
2006 & 11,957 & 484 & 10 & 272 & 1065 & 463 & 2,021 & 7,642 \\
Total & 102,204 & 8059 & 1103 & 2518 & 8697 & 1813 & 25,117 & 54,898 \\
\hline
\end{tabular}

Source: Statistics on Overseas Chinese \& Foreign Investment, Outward Investment, and Indirect Mainland Investment. Investment Commission, Ministry of Economic Affairs.

Note: ASEAN, Association of Southeast Asian Nations.

The unusual amounts of FDI reported in some specific years are due to the government's restrictions on FDI in China. Due to the intense political relationship and a flourishing economic relationship between Taiwan and China, Taiwan's government faces the dilemma of whether or not to regulate FDI by Taiwanese investors in China. The scenario that a large amount of capital outflow to China may help boost the rival nation's economic development has not necessarily been desired by the government and it has therefore introduced regulations governing FDI in China whereby all intended investment cases require an application to the relevant authority for approval. ${ }^{2}$ After the 1996 Missile Crisis, the government adopted a "cautious self-restraint" policy regarding investment in China as a result of which FDI in China was classified into three types, namely, forbidden, special case, and permitted. FDI by the high-tech industries and related infrastructure are particularly strictly regulated.

To meet the requirements for being a member of the World Trade Organization (WTO), the regulatory policy was changed and became based on a new principle of "active open and effective management" in 2001. Under this new policy, FDI in China was narrowed down to just two types, namely, "forbidden" and "general case". This new policy is more relevant to the electronics industry in that many kinds of electronics technologies are reallocated to the classification of "general cases". To promote the efficiency of capital use among listed companies, the government relaxed the restriction on the accumulated sum of FDI in China from $20 \%$ to $40 \%$ of the firm's capital stock. As the FDI in China

2 To skirt the regulation, many large enterprises have transferred capital to another company registered in a tax haven, such as the British Virgin Islands or the British Cayman Islands, and from there have then invested in China. 
policy evolved, the authority gave firms the opportunity to re-register in 1993, 1997, 2002, and 2003, which encouraged firms to report illegal China investments and legalize those investments. ${ }^{3}$

Since the early 2000s, FDI in China has accounted for more than half of Taiwan's total FDI amount, reaching as much as $70 \%$ in 2005 . The phenomenon that FDI is leaning more and more towards China has given rise to serious concerns on the part of the public, especially in terms of how and to what extent FDI in China is affecting the domestic economy. Along with the increased share of R\&D expenditures in China (MOEA, 2007), the government is concerned that the large amount of outward FDI might be accompanied by technology outflows, leading to an erosion in the technological advantages of the country's domestic industries.

Does FDI in China affect Taiwanese MNE's domestic innovative activity and if so, how? In reviewing the literature, the domestic innovation effect of FDI depends on the relative wage, technological opportunities, and market size between the investing and destination countries. Compared with Taiwan, it is apparent that the labour cost is low and that the market size is huge in China. This implies that FDI in China may tend to reduce the MNE's innovative activity in Taiwan. Alternatively, China's technological ability is much lower than that in Taiwan, indicating that the possible reallocation of MNE's R\&D expenditures to China should be regarded as development rather than research expenditures. It is thus helpful for parent firms to devote more efforts to R\&D activity. Therefore, how FDI in China affects the innovative activity of Taiwanese MNE gives rise to no distinct expectations a priori and requires an empirical investigation.

\section{Data sources and descriptive analyses}

To examine the potential impact of FDI on domestic innovation, it may be more suitable to use large enterprises as opposed to small and medium-sized enterprises (SME), because most SME shut down their domestic plants when they decide to invest overseas. Based on the aforementioned discussion on the policy concerning FDI in China, the year 1997 is one of the turning points when the government implemented a more restrictive policy, especially for large firms and the electronics industry. Therefore, this study collects a dataset of large enterprises for the period 1997-2005. The primary database is manufacturing firms listed on the Taiwan Stock Exchange (TSE) between 1997 and 2005. By eliminating a few firms with incomplete data for all relevant variables, we obtain an unbalanced panel data set of 540 enterprises, yielding an overall sample of 4761 observations. ${ }^{4}$ The relevant variables are obtained from various sources. Information on FDI in China and other countries is drawn from the notification data in the Investment Commission of the Ministry of Economic Affairs. Innovation measures adopted in the study include input and output measures, R\&D spending, and the number of patents. The patent count data drawn from the Taiwan Intellectual Property Office (TIPO) database are matched to the accounts data for the period 1997-2005. On the other hand, R\&D

3 One purpose of this measure is to unravel the mystery as to how much capital has flowed into China in reality.

4 There were 20 industry classifications and 682 firms in 2005, with the number of electronics firms accounting for $44 \%$ of the total. 
TABLE 2

Listed enterprises' outward foreign direct investment by locations

\begin{tabular}{|c|c|c|c|}
\hline Year & China & Others & Total \\
\hline 1995 & 431 & - & \\
\hline 1996 & 498 & - & \\
\hline 1997 & 1123 & - & \\
\hline 1998 & 579 & - & \\
\hline 1999 & 492 & - & \\
\hline 2000 & $2056(73.72 \%)$ & $733(26.28 \%)$ & 2789 \\
\hline 2001 & $2021(76.23 \%)$ & $630(23.775)$ & 2651 \\
\hline 2002 & $2763(81.08 \%)$ & $645(18.92 \%)$ & 3408 \\
\hline 2003 & $2102(72.51 \%)$ & $797(27.49 \%)$ & 2899 \\
\hline 2004 & $2438(70.52 \%)$ & $1019(29.48 \%)$ & 3457 \\
\hline 2005 & $1524(88.45 \%)$ & $199(11.55 \%)$ & 1723 \\
\hline
\end{tabular}

Source: Investment Commission, Ministry of Economic Affairs of Taiwan. Figures in parentheses are the foreign direct investment (FDI) to total FDI ratios.

expenditure as well as firm-specific variables, including sales, employment, firm age, fixed capital stock, and profitability, are drawn directly from the firms' annual financial statements. ${ }^{5}$

The major strengths of the present dataset are the high coverage of large Taiwanese MNE and the level of detail of the FDI data, which enables the FDI in China and in other countries for each firm to be distinctly measured. Due to the regulation imposed on listed enterprises that prevents them from engaging in FDI in China, this dataset enables us to take into account the impact of the policy of FDI deregulation on firms' endogenous FDI decisions, which in turn affect the FDI-domestic innovation nexus.

Table 2 shows the FDI statistics of listed enterprises during the period 1995-2005. Similar to the overall trend of FDI in China presented in Table 1, the amount of FDI in China exhibits an upward trend with two spikes in 1997 and 2002. ${ }^{6}$ This raises the question: To what extent has the outward FDI of listed enterprises been concentrated in China? Because the data regarding the listed enterprises' FDI in countries not including China have been reported by the Investment Commission, Ministry of Economic Affairs since 2000, we report the ratio of FDI in China to total FDI for the period 2000-05 in Table 2. The numbers in parentheses clearly indicate that more than $70 \%$ of the FDI engaged in by listed enterprises flowed into China, reaching an overall average of $77 \%$. During the same period, the average ratio of FDI in China to total FDI was about $53 \%$ in Taiwan. The apparent difference between these two ratios illustrates the relatively greater degree of reliance of Taiwan's listed enterprises on China's market and on production there.

Looking further to manufacturing firms, it needs to be asked: which industries engage in the most FDI in China? Are the quantities of outward FDI on the part of high-tech industries that may accompany technology outflows a government concern? From observ-

5 The comprehensive and detailed information regarding firms listed on the TSE is constructed as a databank by the Taiwan Economic Journal.

6 The decrease in 2005 was attributed to the sharp decrease in FDI on the part of electronics firms. 
ing Table 3, several points are worth noting. First, high-tech industries rather than traditional industries account for most FDI, with the electronics industry accounting for more than $60 \%$ of FDI in China. Second, the plastics industry is ranked second in terms of the amount of FDI in China. This large amount of FDI is, however, the result of decisions made by a large petrochemical corporation. Third, besides the electronics industry, the electrical machinery industry and the chemical and biotechnology industry are the main contributors to FDI in China.

We can affirmatively conclude that China is an extremely popular destination country for Taiwan's outward FDI, particularly for listed enterprises. In terms of the FDI in China engaged in by listed enterprises, more than $60 \%$ is contributed by the industry, which is the most R\&D-intensive and the most important in terms of output in Taiwan. Because technology transfer in the MNE is popular, the government is seriously concerned about whether the large amount of FDI in China engaged in by large enterprises, especially electronics firms, is resulting in the technological advantages of Taiwan being eroded away. To make matters worse, the government worries that such outward FDI may reduce the innovation efforts of the domestic parent firms, owing to an FDI strategy that enables them to have a lower overseas production cost. These concerns inspire this study to empirically examine whether and how FDI in China affects the domestic innovation of Taiwanese manufacturing firms.

\section{Empirical specification and estimation techniques}

\subsection{Empirical specification}

To estimate the impact of FDI on domestic innovative activity, we first consider R\&D spending as a measure of innovative activity. By referring to previous studies that discuss the determinants of $\mathrm{R} \& \mathrm{D}$, we utilize the following simple log-linear equation:

$$
\begin{aligned}
\ln R D_{i t}= & \beta_{0}+\beta_{1} \ln S I Z E_{i t}+\beta_{2} A G E_{i t}+\beta_{3} \ln P C A P_{i t}+\beta_{4} G R_{i t}+\beta_{5} P R O F I T_{i t}+\beta_{6} S C I_{i t} \\
& +\beta_{7} C S F D I C_{i t}+\beta_{8} C S F D I D_{i t}+\varepsilon_{i t}
\end{aligned}
$$

The term RD is the R\&D spending by firm $i$ in year $t$.

The explanatory variables include the following three firm characteristics, namely, firm size $(S I Z E)$, firm age $(A G E)$, and capital intensity $(P C A P)$. The size of a firm is measured by the logarithm of employment. Large firms usually have obvious advantages in terms of their ability to support R\&D. The famous Schumpeter hypothesis points out that firms wielding monopolistic power (usually larger firms) tend to engage in innovation and this hypothesis has been supported by many empirical studies. Alternatively, Audretsch and Acs (1991) find that small firms tend to outweigh large firms in terms of innovation performance when operating in a more technology-intensive environment. As for the potential impact of the firm's age on R\&D, incumbent firms have an advantage over their younger counterparts in terms of $\mathrm{R} \& \mathrm{D}$ management. Therefore, there is a positive relationship between firm age and $\mathrm{R} \& \mathrm{D}$. The term $\ln P C A P$ denotes a firm's capital intensity, measured as the logarithm of physical capital per employee. A firm with a higher capital intensity usually engages in more R\&D to improve its production process in Taiwan. We therefore observe a positive association between capital intensity and R\&D.

Firms' sales growth $(G R)$ is usually regarded as a proxy for market demand, and has a positive impact on the firms' $R \& D$. Conversely, $R \& D$ activity is widely found to be 
The Japanese Economic Review

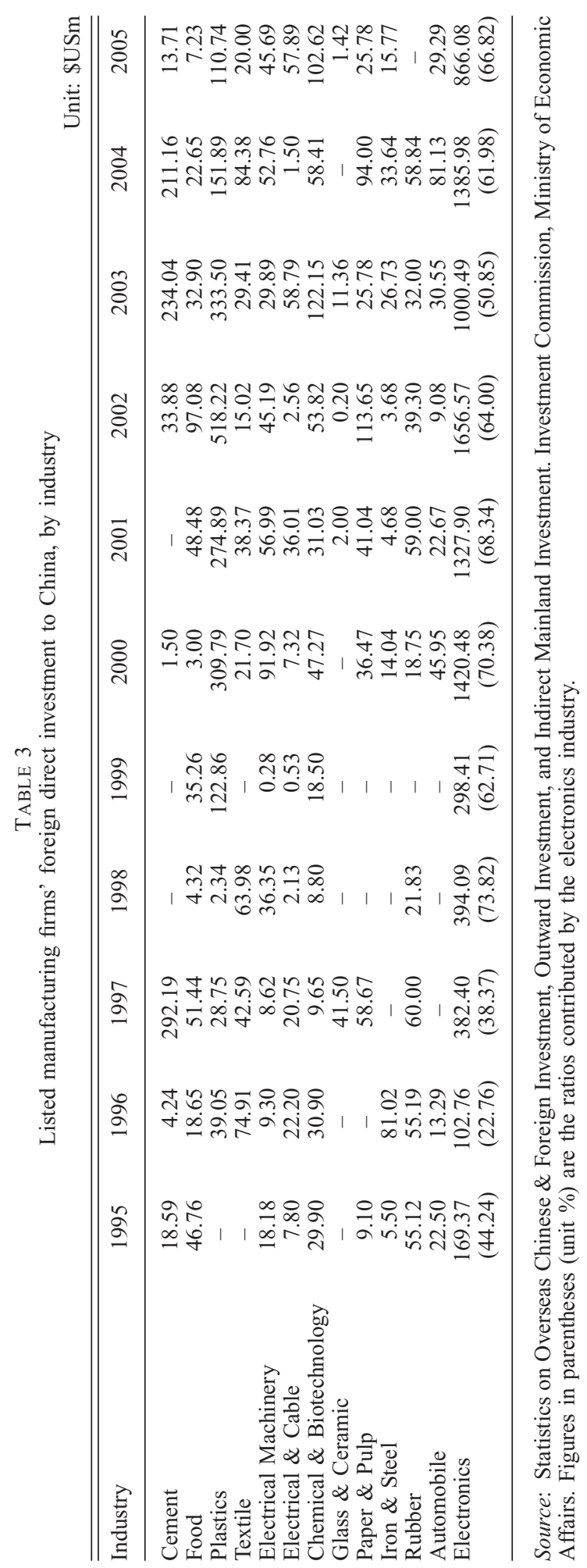


countercyclical as firms may devote more efforts to R\&D during a slowing economy. ${ }^{7}$ A firm's profitability (PROFIT) is also included to measure the availability of internal financial resources and is expected to have a positive impact on firms' innovations. To control for the inter-industry differences in technological opportunities, we include an industry dummy that equals one if a firm belongs to a scientific industry.

We now turn to the major issue of how FDI in China affects domestic R\&D. Previous studies, such as Head and Ries (2002) and Lin and Yeh (2005), include the variable for the current flow of FDI or the FDI dummy and examine its impact on domestic R\&D. This specification is flawed, because the potential impact of FDI is not felt all at once. Once the foreign affiliate is established, it will continue to operate and it is then possible that the firm's innovation strategy will be affected. Therefore, a stock measure of FDI is more appropriate than the flow measure. As discussed in the previous section, the government set an upper limit of $20 \%$ of the capital stock for the accumulated sum of FDI in China for listed enterprises and then relaxed this restriction to $40 \%$ in 2001 . To capture the FDI stock concept as well as to consider the policy's impact, the FDI variable adopted in this study is the ratio of accumulated FDI in China to the capital stock (CSFDIC). The policy of imposing an upper limit on FDI in China is widely criticized by listed enterprises as is slows down their ability to make internal arrangements in regard to production, logistics distribution, and innovative activity as they seek to become more globalized. It is generally argued that MNE may transfer technologies from the home country to their foreign affiliates as well as increase the share of R\&D undertaken by foreign affiliates. The estimate of the coefficient for CSFDIC can be used to assess whether there is a negative impact on domestic R\&D, thereby shedding light on the FDI policy.

Outward FDI to developed countries is treated as one way in which Taiwanese firms can acquire and access advanced technologies (Chen and Yang, 1999). Therefore, the ratio of accumulated FDI in developed countries to capital (CSFDID) is also included and is expected to have a positive impact on domestic R\&D. ${ }^{8}$

The potential impact of FDI on domestic innovative activity may emerge in terms of $R \& D$ productivity rather than $R \& D$ spending. When MNE decide on the international allocation of $R \& D$ activity, $R \& D$ undertaken by foreign affiliates located in developing countries is usually adaptation-oriented, whereas home $R \& D$ tends to be more basic. Basic R\&D is time-consuming as well as money-consuming. It is also risky in that the probability of successfully developing a new product and processing the basic R\&D commercially is extremely low. This suggests that basic R\&D usually results in fewer patentable goods compared with those produced through adaptation-oriented R\&D. Therefore, such an allocation of R\&D may alternatively reduce the R\&D productivity in terms of patents, even though $R \& D$ spending remains at the same level in the MNE's parent firms.

To examine the relationship between FDI, especially FDI in China, and the productivity of domestic $R \& D$, we use patents to represent the output of $R \& D$ in order to assess the effect of FDI on R\&D productivity and specify the following empirical equation: ${ }^{9}$

7 For example, Rafferty (2003).

8 The ratio of FDI in other developing countries to total FDI is very low; so we do not consider its impact in this study.

9 This equation can be derived from a patent production function developed by Hausman et al. (1984). 


$$
\begin{aligned}
P A T_{i t}= & \beta_{0}+\beta_{1} \ln R D_{i t}+\beta_{2} \ln S I Z E_{i t}+\beta_{3} A G E_{i t}+\beta_{4} \ln P C A P_{i t}+\beta_{5} G R_{i t}+\beta_{6} P_{R O F I T_{i t}} \\
& +\beta_{7} S C I_{i t}+\beta_{8} C S F D I C_{i t}+\beta_{9} C S F D I D_{i t}+\varepsilon_{i t} .
\end{aligned}
$$

Here, PAT refers to the successful application of the patents of firm $i$ in year $t$. The explanatory variables are the same as those in Equation (1) plus R\&D spending. Table 4 summarizes the definitions of the variables and the summary statistics of the variables used in the estimations.

In exploring the relationship between FDI and domestic innovative activity, we allow for the existence of the individual effect which is potentially correlated with the righthand side of the regressors:

$$
\varepsilon_{i t}=u_{i}+v_{i t} .
$$

Here, $u$ is a firm-specific effect that varies across firms, but is consistent within a firm over time, and $v$ is a "white noise" error term. To deal with the unobservable individual effect in a panel data model, we apply both random effects (RE) and fixed effects (FE) models that treat the individual effect as a random variable and a fixed parameter, respectively. The Hausman test is employed to judge which model is more appropriate. Moreover, in Equation (2) the patent count is a discrete variable and some observations assume a value of zero, thereby rendering the classical linear model inadequate. For count data, the linear exponential family provides a good alternative, and Poisson-based count data models and estimation methods are used in this analysis. The Poisson model has a strict limitation in that the mean and variance are equal, but this assumption hardly holds. We therefore employ and estimate the negative binomial models using count panel data.

One econometric problem that we encounter in the estimation procedure relates to the existence of endogenous causality between FDI and innovations. This study therefore first uses the Wu-Hausman test to detect the existence of the endogeneity problem. If no endogeneity is found, the panel fixed effects model technique is employed to deal with the unobserved firm heterogeneity. On the other hand, when the endogeneity is detected, the generalized method of moments (GMM) provides an alternative technique. By using an

TABLE 4

Variable definitions and basic statistics

\begin{tabular}{llr}
\hline \hline Variables & & \multicolumn{1}{c}{$\begin{array}{c}\text { Mean } \\
\text { (standard error) }\end{array}$} \\
\hline RD & R\&D expenditure (\$NTm) & $183.755(671.231)$ \\
PAT & Number of granted patents & $8.050(47.225)$ \\
SIZE & Firm size: measured by the number of employees & $950.438(2141.861)$ \\
AGE & Firm age & $21.901(12.542)$ \\
PCAP & Capital intensity: measured by fixed assets per employee & $27.507(15.401)$ \\
& $\quad$ (\$NTm/employee) & \\
GR & Sales growth (\%) & $0.775(14.430)$ \\
PROFIT & Profitability (\%) & $13.753(281.055)$ \\
SCI & Industry dummy. Scientific industries = 1. Scientific industries include & $0.730(0.444)$ \\
& $\quad$ Petrochemical, Electrical Machinery, Chemical \& Biotechnology, & \\
& Electrical \& Cable, Automobile, and Electronics. & $14.671(29.960)$ \\
CSFDIC & Ratio of accumulated China investment to capital stock (\%) & $2.547(18.644)$ \\
CSFDID & Ratio of accumulated investment in developed countries to capital stock & \\
& (\%) & \\
\hline
\end{tabular}


adequate instrumental variable to deal with the endogenous variable, this approach provides asymptotically efficient estimators even under a weak assumption regarding the disturbance. It is also robust in the presence of heteroskedasticity across firms, and exhibits correlation among the disturbances within countries over time.

A qualified instrumental variable should be highly correlated with FDI in China, but should be uncorrelated with the error term. Thus, we adopt the policy measures as the instrumental variables for FDI in China. As mentioned previously, the policy in regard to FDI in China was transformed from one of "cautious self-restraint" in 1996 to "active open and effective management" in 2001. This policy transformation has affected the current behaviour of FDI in China rather than other firm conduct, revealing that it is appropriate to serve as the instrumental variable for investment in China. This study separates the sample into two sub-groups: the control group that includes firms not influenced by the policy, and the treatment group that consists of firms impacted by the open policy.

\section{Empirical results}

Before empirically estimating the innovation equations, we first examine the potential endogenous causality between FDI in China and R\&D. Table 5 reports the estimates of the Wu-Hausman test on the endogeneity of FDI in China.

The coefficients of RES_CSFDIC in Models 1 and 2 are substantially different. Using $\mathrm{R} \& \mathrm{D}$ expenditure as the dependent variable, the coefficient of the RES_CSFDIC variable is positive and significantly greater than zero at the $1 \%$ level, indicating that the ratio of

TABLE 5

$\mathrm{Wu}-$ Hausman test for the endogeneity of foreign direct investment in China

\begin{tabular}{|c|c|c|}
\hline Dependent variable & $\ln R D$ & Patents \\
\hline Constant & $-10.905(0.726)^{* * *}$ & $-3.604(0.369)^{* * *}$ \\
\hline $\ln R D$ & & $0.114(0.013)^{* * *}$ \\
\hline $\operatorname{lnSIZE}$ & $1.849(0.077)^{* * *}$ & $0.059(0.034)^{*}$ \\
\hline AGE & $0.183(0.014)^{* * *}$ & $0.053(0.004)^{* * *}$ \\
\hline $\ln P C A P$ & $1.330(0.174)^{* * *}$ & $0.145(0.084)^{*}$ \\
\hline GR & $-0.008(0.002)^{* * *}$ & $0.007(0.002)$ \\
\hline PROFIT & $0.135 \mathrm{E}-3 \quad(0.279 \mathrm{E}-03)$ & $0.002(0.002)$ \\
\hline CSFDIC & $-0.005(0.003)$ & $0.002(0.001)^{* *}$ \\
\hline CSFDID & $0.011(0.004)^{* * *}$ & $-0.004(0.004)$ \\
\hline RES_CSFDIC & $0.794(0.229) * * *$ & $-0.093(0.089)$ \\
\hline $\mathrm{R}^{2}-$ & 0.213 & \\
\hline Log-likelihood & & -5416 \\
\hline Obs & 4761 & 4761 \\
\hline
\end{tabular}

Notes: The numbers in parentheses are standard errors. $* * *, * *$, and $*$ represent statistical significance at the $1 \%, 5 \%$, and $10 \%$ levels, respectively. RES_CSFDIC is the residual obtained from the following regression.

$$
\text { CSFDIC }_{i t}=\alpha_{0}+\alpha_{1} \ln S_{Z Z E_{i t}}+\alpha_{2} \ln \text { PCAP }_{i t}+\alpha_{3} T_{I M E_{i t}}+\alpha_{4} T R E A T_{i t}+\alpha_{5} T_{I M E_{i t}} * T R E A T_{i t}+\varepsilon_{i t}
$$

TIME is a time dummy that equals unity for the time period after November 2001. TREAT is an industry dummy that equals unity for regulated industries. See Table 4 for definitions. 
accumulated FDI in China to the capital stock (CSFDIC) is mutually causal with R\&D expenditure. Therefore, the GMM technique is appropriate when we estimate the R\&D equation. On the other hand, the estimated coefficient of RES_CSFDIC is negative and not significant at a conventional level, implying that there is no endogenous causality between investment in China and patents.

\subsection{FDI in China and the domestic R\&D level}

Table 6 reports a series of estimates of the R\&D equation specified in Equation (1). Columns 1 and 2 show the results obtained from the random effects and fixed effects of the panel data model, respectively. Column 3 displays the regression results using GMM that are employed to correct for bias due to the endogenous causality between FDI in China and R\&D behaviour. Because the $S C I$ variable is time invariant, it is excluded from the estimates of the fixed effects model and the panel fixed GMM.

The coefficients of $\ln S I Z E$ and $\ln P C A P$ are both positive and significantly greater than zero at the $1 \%$ level for all estimates, indicating that an increase in firm size and/or capital intensity leads to an increase in R\&D expenditure. The results support the Schumpeter hypothesis that larger firms tend to engage in innovation. Moreover, the findings indicate that capital-intensive enterprises tend to devote more efforts to R\&D in Taiwan. The coefficient of firm age is positively significant in columns 1 and 2, but is negatively significant in the panel fixed GMM (column 3). The contrasting results of the firm age coefficient suggest that the neglect of the endogeneity problem may result in biased coefficient estimates for some variables. Why are younger firms more devoted to R\&D spending than older firms? A possible interpretation is that most young firms in our sample are electronics firms that are more likely to engage in $R \& D$ and set aside more resources for R\&D.

TABLE 6

The Effect of foreign direct investment in China on Domestic R\&D Expenditure

\begin{tabular}{|c|c|c|c|}
\hline & \multicolumn{2}{|c|}{ Panel data model } & \multirow{2}{*}{$\begin{array}{l}\text { Panel fixed generalized } \\
\text { method of moments }\end{array}$} \\
\hline & Random & Fixed & \\
\hline Constant & $-12.818 * * *(0.714)$ & $-13.366^{* * *}(0.682)$ & $-2.779(3.177)$ \\
\hline $\operatorname{lnSIZE}$ & $2.074 * * *(0.065)$ & $2.173 * * *(0.072)$ & $1.231 * * *(0.310)$ \\
\hline AGE & $0.060 * * *(0.010)$ & $0.179 * * *(0.014)$ & $-0.452 * * *(0.140)$ \\
\hline $\ln P C A P$ & $1.125 * * *(0.153)$ & $1.478 * * *(0.168)$ & $2.409 * * *(0.592)$ \\
\hline GR & $-0.007 * * *(0.003)$ & $-0.006^{* *}(0.003)$ & $0.001(0.008)$ \\
\hline PROFIT & $0.142 \mathrm{E}-3 \quad(0.209 \mathrm{E}-03)$ & $-0.131 \mathrm{E}-03 \quad(0.284 \mathrm{E}-03)$ & $-0.406 \mathrm{E}-04 \quad(0.946 \mathrm{E}-03)$ \\
\hline SCI & $5.134 * * *(0.356)$ & dropped & dropped \\
\hline CSFDIC & $0.006 * * *(0.002)$ & $0.002(0.002)$ & $0.414 * * *(0.087)$ \\
\hline CSFDID & $0.010 * * *(0.004)$ & $0.011 * * *(0.004)$ & $-0.007(0.013)$ \\
\hline $\mathrm{R}^{2}$ & 0.261 & 0.273 & \\
\hline F (first stage) & & & $340.63 * * *$ \\
\hline Obs & 4761 & 4761 & 4761 \\
\hline
\end{tabular}

Notes: The numbers in parentheses are standard errors. ***,**, and * represent statistical significance at the $1 \%, 5 \%$, and $10 \%$ levels, respectively. We relate the first stage of the CSFDIC equation to lnSIZE, AGE, InPCAP, GR, PROFIT, SCI, InRD, CSFDID, TIME, TREAT, and TIME*TREAT. The F statistic is the weak IV test. The null hypothesis is rejected when the $\mathrm{F}$ value is larger than 10 , indicating that the adopted IV is effective. See Table 4 for definitions. 
As for the influences of other variables, firm growth and profitability are not expected to be positively associated with $R \& D$ expenditure. One possible reason is that the relationship between firm growth (profitability) and R\&D is nonlinear. Firms with high growth (profitability) or negative growth (profitability) may be the most aggressive in regard to R\&D than the medium growth group, resulting in a mixed effect. As shown by the random effects model, the time invariant variable $S C I$ is associated with a significantly positive coefficient, thus revealing the importance of technological opportunities to a firm's R\&D activity.

It is both interesting and important to note that the estimates of FDI in China differ quite markedly when the endogenous decision to engage in FDI in China is considered compared with when it is not. Although the coefficients in columns 1 and 2 are positive, their magnitudes are highly underestimated compared with those obtained using the panel fixed GMM. The significantly positive coefficient of CSFDIC in column 3 suggests that there is a positive association between FDI in China and domestic R\&D that is consistent with the finding in Lin and Yeh (2005). The estimated elasticity is 0.414 , implying that as the ratio of accumulated FDI in China to capital stock increases by $1 \%$, the R\&D expenditure rises by $0.414 \%$. On the other hand, the effect of CSFDID on $\mathrm{R} \& \mathrm{D}$, as expected, is not significantly positive in the GMM estimates. Technology sourcing is one of the reasons why Taiwanese firms invest in developed countries. Even though establishing affiliates in developed countries is helpful for the investing firm seeking to improve its technological capability, it may induce the MNE to lower the level of domestic R\&D or establish their R\&D affiliates in the destination country. This finding seems to be consistent with the argument by Belderbos et al. (2006) that investing in countries with relatively more technological opportunities (developed countries) may have a substitutive effect on domestic R\&D.

With regard to the current debate, the effects of FDI on the Taiwan economy can be examined from various perspectives, such as employment, investment, trade, and innovation. The above estimates regarding the $R \& D$ effect of FDI are quite interesting in that FDI in China has a positive effect on the domestic R\&D of Taiwanese MNE, whereas FDI in developed countries has no significant impact on parent firms' R\&D expenditures in Taiwan. The contrasting results for the R\&D impact of FDI are not surprising: as indicated by Chen and Yang (1999) and the Ministry of Economic Affairs (2007), the FDI in China is mainly cost-oriented, aiming to reallocate production lines in China by utilizing cheaper local labour. Shifting part of its production activities abroad may increase a firm's total sales due to lower labour costs or market expansion induced by its FDI. The greater the sales, the greater the output over which it can average the costs of $R \& D$ and hence the greater its returns from R\&D. Meanwhile, Taiwanese MNE locate their R\&D activity and the production of high-end products in Taiwan, in order to retain their international competitiveness. While there is both market-oriented and resourceoriented $R \& D$ that might induce an increase in the R\&D conducted by affiliates in China, Taiwanese MNE tend to keep most of their innovative activity in the domestic market, because the strength of intellectual property rights (IPR) protection is extremely weak in China, meaning that MNE suffer a serious threat of imitation and knowledge outflow as they engage in R\&D activity in China. Alternatively, the purpose of FDI in developed countries is mainly focused on accessing advanced technologies and knowledge in the host countries, suggesting that the FDI in developed countries is usually accompanied by the outflow of R\&D activity through the establishment of overseas R\&D affiliates (Chen and Yang, 1999). It then crowds out the R\&D resources used domestically, resulting in an insignificantly negative impact as observed in the right column of Table 6. 


\subsection{FDI in China and domestic R\&D productivity}

While the aforementioned analysis shows that the domestic R\&D level is not reduced by engaging in FDI in China, whether or not the R\&D productivity is influenced is another concern. By employing the negative binomial model for count panel data, the estimates for Equation (2) are shown in Table 7.

The estimates obtained from the random effects and fixed effects models are quite similar. The estimated patent elasticity of R\&D is between 0.122 and 0.164 , which is slightly lower than that obtained in Yang and Chen (2001) by using similar data over the period 1990-97. This implies that R\&D productivity in terms of patenting is decreasing, yet it needs to be further examined. Again, Schumpeter's hypothesis that large firms tend to have the wherewithal to exploit innovations is supported, because the estimated coefficient of $\ln S I Z E$ is positive and statistically significant at the $1 \%$ level.

In contrast to the GMM estimates for the R\&D equation, firm age is found to be significantly and positively associated with patenting. This result is attributed to the learning effect of patent management. The knowledge as to how to apply for patents and to what extent the innovations are patentable is accumulated along with the passage of time and therefore the experience in regard to patenting can increase the firms' $R \& D$ productivity in relation to patenting. The estimated coefficient of capital intensity is positive and significant at the $10 \%$ statistical level in the fixed effects model. Due to the large sunk costs, capital-intensive firms tend to apply for more patents to construct a portfolio of intangible assets in terms of patents, because the portfolio of patents helps firms to maintain their competitiveness in industries with rapid technological change. Moreover, it can be clearly seen that the coefficient for SCI is both positive and significant at the $1 \%$ statistical level. Firms belonging to scientific industries have a patenting propensity that is a surprising $189 \%(=\exp (1.061)-1)$ higher on average, indicating the importance of technological opportunities to patenting after controlling for other firm characteristics.

Turning to the impact of FDI with which we are concerned, the coefficients of CSFDIC in the random and fixed effects models are both positive and significantly greater than zero at the $5 \%$ level. The estimated elasticity is 0.002 , indicating that a firm with a $1 \%$

TABLE 7

Effect of foreign direct investment in China on Domestic R\&D Productivity

\begin{tabular}{|c|c|c|}
\hline & Random Effect & Fixed Effect \\
\hline Constant & $-4.929 * * *(0.312)$ & $-3.645 * * *(0.364)$ \\
\hline $\ln R D$ & $0.164 * * *(0.013)$ & $0.122 * * *(0.013)$ \\
\hline $\operatorname{lnSIZE}$ & $0.154 * * *(0.032)$ & $0.062 *(0.034)$ \\
\hline AGE & $0.040 * * *(0.004)$ & $0.054 * * *(0.004)$ \\
\hline $\ln P C A P$ & $-0.026(0.073)$ & $0.128 *(0.078)$ \\
\hline GR & $0.001(0.002)$ & $0.895 \mathrm{E}-03(0.001)$ \\
\hline PROFIT & $0.004 * *(0.002)$ & $0.003(0.002)$ \\
\hline SCI & $1.061 * * *(0.145)$ & dropped \\
\hline CSFDIC & $0.002 * * * \quad(0.781 \mathrm{E}-03)$ & $0.002 * *(0.829 \mathrm{E}-03)$ \\
\hline CSFDID & $-0.003(0.003)$ & $-0.004(0.004)$ \\
\hline Log-likelihood & -7536 & -5422 \\
\hline Obs & 4761 & 4761 \\
\hline
\end{tabular}

The numbers in parentheses are standard errors. ***,**, and * represent statistical significance at the $1 \%, 5 \%$, and $10 \%$ levels, respectively. See Table 4 for definitions. 
higher FDI in China ratio tends to have $0.002 \%$ more domestic patents after controlling for $R \& D$ expenditure and other variables. Despite the productivity effect being very trivial, it does provide at least some evidence that, at least in the short run, FDI in China does not lead to a reduction in domestic R\&D productivity, which is a concern of the government. Alternatively, the estimated coefficient of CSFDID is negative but not significant for all estimates, suggesting that investments in developed countries have no impact on the parent firms' domestic patenting.

The contrasting results for the impacts of FDI in China and the developed countries on $\mathrm{R} \& \mathrm{D}$ productivity in terms of domestic patenting are consistent with the findings in the previous subsection. If FDI in China induces MNE to reallocate more R\&D activity domestically, the scope effect of diversified $R \& D$ is helpful to firms as they apply for more patents, ceteris paribus. By contrast, the amount of $\mathrm{R} \& \mathrm{D}$ expenditure remains much the same as firms invest in developed countries and it then has no significant impact on domestic patenting.

\subsection{The effect of FDI in China on innovation in the electronics industry}

As much of the FDI in China has been contributed by large electronics firms over the past decade and the electronics industry is particularly important in terms of outputs, exports, employment, and innovations in Taiwan, the question as to the potential effect of FDI in China on the electronics firms' innovations is of great concern to the government. To investigate whether the effect of FDI in China on domestic innovations exhibits a different pattern in the electronics industry, we extract the electronics firms from the sample and then implement similar econometric techniques to those used in constructing Table 6 and 7 before reporting the estimates for the electronics firms in Table 8 .

TABLE 8

Effects of foreign direct investment in China on domestic electronics firms' innovations

\begin{tabular}{|c|c|c|}
\hline Dep. variable & $\begin{array}{l}\text { Fixed effects of panel } \\
\text { model generalized method } \\
\text { of moments } \\
\operatorname{lnRD}\end{array}$ & $\begin{array}{l}\text { Negative binomial model } \\
\text { Fixed effects } \\
\text { Patent }\end{array}$ \\
\hline Constant & $-9.168 * * *(1.666)$ & $-3.721 * * *(0.303)$ \\
\hline $\operatorname{lnRD}$ & & $0.142 * * *(0.015)$ \\
\hline $\operatorname{lnSIZE}$ & $1.739 * * *(0.225)$ & $0.061 *(0.038)$ \\
\hline AGE & $-0.080(0.087)$ & $0.050 * * *(0.005)$ \\
\hline $\ln$ PCAP & $2.064 * * *(0.447)$ & $0.130(0.088)$ \\
\hline GR & $-0.002(0.006)$ & $0.934 \mathrm{E}-03 \quad(0.002)$ \\
\hline PROFIT & $0.113 \mathrm{E}-3 \quad(0.619 \mathrm{E}-03)$ & $0.003(0.002)$ \\
\hline CSFDIC & $0.198 * * *(0.047)$ & $0.160 \mathrm{E}-02 *(0.882 \mathrm{E}-03)$ \\
\hline CSFDID & $-0.044(0.031)$ & $0.632 \mathrm{E}-03(0.005)$ \\
\hline F (first stage) & $193.51 * * *$ & \\
\hline Obs & 2705 & 2705 \\
\hline
\end{tabular}

Notes: The numbers in parentheses are standard errors. ***,**, and * represent statistical significance at the $1 \%, 5 \%$, and $10 \%$ levels, respectively. We relate the first stage of the CSFDIC equation to $\operatorname{lnSIZE}$, AGE, InPCAP, GR, PROFIT, SCI, lnRD, CSFDID, TIME, TREAT, and TIME*TREAT. The F statistic is the weak IV test. The null hypothesis is rejected when the $\mathrm{F}$ value is larger than 10 , indicating that the adopted IV is effective. See Table 4 for definitions. 
The results presented in Table 8 suggest that the determinants of $R \& D$ expenditure and patenting are overall similar to those in Tables 6 and 7, while there are also several points worth noting. First, the estimates of R\&D expenditure in column 1 show that the impact of firm age on R\&D expenditure turns out to be insignificant for the electronics firms. As is well known, the technological change is very rapidly accompanied by a short product cycle, and R\&D investment becomes an essential input for the electronics firms. Given the importance of R\&D to the electronics industry, both young entrants and older incumbents are aggressive in terms of innovative activity. Therefore, firm age does not appear to matter to $R \& D$ expenditure. Second, the estimates of $R \& D$ productivity in column 2 show that the impact of capital intensity on patenting turns out to be insignificant.

Third and most importantly, the effect of FDI in China on domestic innovations seems to vary in terms of its strength between the whole sample and the electronics firms. In column 1 the coefficient of CSFDIC is still significantly positive at the $1 \%$ level, while the estimated magnitude is only $47.83 \%$ ( 0.198 compared to 0.414$)$ of that for the whole sample. This situation applies to the estimates of R\&D productivity in column 2 . The estimated sign of the CSFDIC variable remains positive, but both the magnitude and significance of the coefficient decrease, from $0.002-0.0016$ and from $5 \%$ to $10 \%$, respectively. This implies that the strength of the positive impact of FDI in China on domestic $\mathrm{R} \& \mathrm{D}$ expenditure and $\mathrm{R} \& \mathrm{D}$ productivity is weaker for electronics firms.

Why is the domestic innovation effect of FDI in China smaller for electronics firms? That is, while the positive aspect is also found across electronics firms, such firms may concentrate more $R \& D$ in their China affiliates relative to their non-electronic firm counterparts, resulting in their having a smaller impact on domestic innovations. Indeed, Chen (2004) has found that $R \& D$ activities have very rapidly become involved in Taiwanese electronics firms' outreach into China over the last decade. Compared to other manufacturing firms, electronics firms place greater reliance on R\&D to maintain their competitiveness and therefore engage in more R\&D efforts on average. However, in response to the development of a global production network, Taiwanese electronics firms have scaled down their local operations and handed over part, or the whole, of their manufacturing functions to their offshore sites, mainly in China. Following closely on from this, the de-linking of manufacturing and $\mathrm{R} \& \mathrm{D}$ has become a reality, with these Taiwanese firms relying increasingly on their Chinese subsidiaries for production-related R\&D and engineering support (Chen, 2004). The market-oriented and resource-oriented R\&D brought on by FDI in China might induce electronics MNE to devote more R\&D to their Chinese affiliates. Another possibly important reason is that electronics firms have to connect with the global innovation system, because many internationally renowned electronics corporations have established overseas R\&D affiliates in China.

As previously claimed, the strategy adopted regarding FDI in China may serve as a form of resource reallocation that moves production lines to low-cost countries and enables the domestic firms to maintain their core competitiveness through their innovations. The smaller impact on domestic R\&D that FDI has in China implies that the activity of technology transfer might be more popular in the electronics industry - that is, the gains from R\&D are distributed between plants in Taiwan and China. From a dynamic perspective, as both the market and the real income of the FDI destination grow, MNE will consider how to allocate R\&D between the overseas and domestic locations. This might be the main concern of the government and a reason why it has not attempted to fully deregulate the restrictions regarding FDI in China in so far as they affect large electronics firms. 


\section{Conclusions and policy implications}

Due to the high share of outward FDI to China and the special political relationship between the two sides of the Taiwan Strait, the effect of FDI in China on Taiwan's economy is a matter of great concern to both the public and the government in Taiwan. Some of the potential influences include whether or not FDI in China results in an erosion of Taiwan's technological advantages or else induces outflows of technology to China. The government has therefore adopted various regulations on FDI in China, especially for large electronics enterprises in different periods.

This study aims to empirically assess whether or not and how FDI in China affects domestic innovative activity. Utilizing listed enterprises as the study sample and employing the GMM technique enables us to control for the endogenous causality between FDI and innovation and takes into account the impact of a change in policy on FDI. The empirical results show that the FDI in China overall has a positive association with domestic $R \& D$ expenditure and $R \& D$ productivity. This positive effect is also found for electronics firms, although the impact is much smaller. Moreover, the effect of FDI on domestic innovation suffers from bias that arises due to underestimation if the endogeneity problem is not appropriately dealt with.

Several policy implications result from this study. First, our findings show that, at least for the study period, FDI in China exhibits a positive relationship with domestic innovation, rather than having a negative impact as the Taiwan government has feared. It implies that moving production lines to China is the strategy adopted by firms due to global allocation. For most of Taiwan's FDI to be concentrated in China is a natural consequence due to the relative advantages that China has compared with other destinations. Second, as for the current debate, the effects of FDI in China on the Taiwan economy can be examined from various perspectives, such as trade, employment, investment, and productivity. While FDI in China has a positive effect on domestic innovation, the total effect after considering multiple dimensions is not clear and is beyond the purpose of this study. From the perspective of innovation, the regulation directed at listed enterprises in regard to FDI in China can be further relaxed, while the innovation effect arising from resource allocation through FDI is quite limited. Alternatively, FDI in China is found to have a negative impact on Taiwan's employment (Chen and $\mathrm{Ku}, 2003$ ) and investment (Chen, 2006). Therefore, whether or not the regulation of FDI in China in relation to listed enterprises should be relaxed and/or to what extent this regulation is relaxed are both issues that need further investigation after considering the possible impacts of various economic dimensions.

Third, the positive innovation effect of FDI in China is very small in the case of the electronics industry. As with the theoretical arguments in Belderbos et al. (2006) and Tsai and Chiou (2007), the larger the host country's market, the more likely it is that the MNE's R\&D investment in the home country will decrease. China's persistently high economic growth has gradually attracted MNE to establish their Asian R\&D headquarters in China, in order to meet the needs of the local market there. This situation seems to apply to some of the Taiwanese electronics MNE. From a dynamic perspective, how to maintain the technological advantages is particularly relevant to Taiwan's sustainable economic growth. Finally, due to the special political relationship between Taiwan and China, it is inevitable for the government to adopt economic measures from a political perspective. However, in view of the current wave of globalization, both production abroad and international outsourcing are popular and important methods that are being 
used to lower the costs of MNE, indicating that it is impossible to fully block FDI in China. Having a policy in regard to FDI in China is indeed relevant to the Taiwan economy, and thus the government should devote more attention to finding ways to improve the local investment environment in order to attract returning investment from China and FDI from other countries.

Final version accepted 13 July 2009.

\section{REFERENCES}

Audretsch, D. B. and Z. J. Acs (1991) "Innovation And Size at the Firm Level", Southern Economic Journal, Vol. 67, No. 4, pp. 739-744.

Belderbos, R., E. Lykogianni and R. Veugelers (2006) "Strategic R\&D Location by Multinational Firms: Spillovers, Technology Sourcing and Competition”, CEPR Discussion Paper, No. 5060.

_ K. Fukao and T. Iwasa (2006) "Foreign and Domestic R\&D Investment", International Centre for the Study of East Asian Development, Working Paper Series, 2006-2001.

Chen, C. L. and F. S. Hsu (2003) "Defensive Foreign Direct Investment and Endogenous R\&D", Academia Economic Papers, Vol. 31, No. 4, pp. 577-603.

Chen, J. R. and C. H. Yang (1999) "Determinants of Taiwanese Foreign Direct Investment: Comparison between Expansionary FDI and Defensive FDI", Taiwan Economic Review, Vol. 27, No. 2, pp. 215-240.

Chen, S. H. (2004) "Taiwanese IT Firms' Offshore R\&D in China and the Connection with the Global Innovation Network", Research Policy, Vol. 33, No. 2, pp. 337-349.

Chen, T. J. and Y. H. Ku (2000) "The Effect of Foreign Direct Investment on Firm Growth: The Case of Taiwan's Manufacturers", Japan and the World Economy, Vol. 12, No. 2, pp. 153-172.

— and _ (2003) "The Effects of Overseas Investment on Domestic Employment", NBER Working Paper, No. 10156.

Chen, Y. Y. (2006) “The Effects of Foreign Direct Investment on Firm Growth: The Case of Taiwan's Listed Companies", Masters Thesis, National Chiao-Tung University.

Co, C. Y. and J. A. List (2004) "Is Foreign Direct Investment Attracted to 'Knowledge Creators'?", Applied Economics, Vol. 36, No. 11, pp. 1143-1149.

Cohen, W. and S. Klepper (1996) "A Reprise of Size and R\&D”, Economic Journal, Vol. 106, No. 6, pp. $925-951$.

Dunning, J. H. (1988) “The Eclectic Paradigm of International Production: A Restatement and Some Possible Extension", Journal of International Business Studies, Vol. 19, No. 1, pp. 1-31.

_ (1998) "Location and the Multinational Enterprise: A Neglected Factor?" Journal of International Business Studies, Vol. 29, No. 1, pp. 45-65.

Fors, G. (1997) "Utilization of R\&D Results in the Home and Foreign Plants of Multinationals", Journal of Industrial Economics, Vol. 45, No. 3, pp. 341-358.

Hausman, J. A., B. H. Hall and Z. Griliches (1984) "Econometric Models for Count Data with an Application of the Patents-R\&D Relationship", Econometrica, Vol. 52, No. 4, pp. 909-938.

Head, K. and J. Ries (2002) "Offshore Production and Skill Upgrading by Japanese Manufacturing Firms", International Journal of Economics, Vol. 58, No. 1, pp. 81-105.

Kogut, B. and S. J. Chang (1991) "Technological Capabilities and Japanese Foreign Direct Investment in the United States", Review of Economics and Statistics, Vol. 73, No. 3, pp. 401-413.

Lin, H. and R. S. Yeh (2005) "The Interdependence between FDI and R\&D: An Application of an Endogenous Switching Model to Taiwan's Electronics Industry”, Applied Economics, Vol. 37, No. 15, pp. 1789-1799.

Lispey, R. E. (1994) "Outward Direct Investment and the US Economy”, NBER Working Paper, No. 4691.

Ministry of Economic Affairs (MOEA) (2007) Report on Foreign Investment Strategies of the Manufactures. Taipei: Ministry of Economic Affairs.

Petit, M. L. and F. Sanna-Randaccio (1998) "Technological Innovation and Multinational Expansion: A Two-Way Link?” Journal of Economics, Vol. 68, No. 1, pp. 1-26.

- and - (2000) "Endogenous R\&D and Foreign Direct Investment in International Oligopolies", International Journal of Industrial Organization, Vol. 18, No. 2, pp. 339-367.

Rafferty, M. (2003) "Do Business Cycles Alter the Composition of Research and Development Expenditures?", Contemporary Economic Policy, Vol. 21, No. 3, pp. 394-405.

Slaughter, M. J. (2000) "Production Transfer within Multinational Enterprises and American Wages", Journal of International Economics, Vol. 50, No. 2, pp. 449-472.

Suh, J. (2005) "Enhancing Productivity through Innovation: Korea's Response to Competitiveness Challenges", Korean Development Review, Vol. 27, No. 2, pp. 205-231. 


\section{C-H. Yang, Y-Y. Wu, H-L. Lin: FDI and Domestic Innovation}

Tsai, Y. C. and J. R. Chiou (2007) "Foreign Direct Investment and Research and Development", Academia Economic Papers, Vol. 35, No. 1, pp. 53-82.

United Nations (2005) World Investment Report: Transnational Corporations and the Internalization of R\&D. New York and Geneva: United Nations.

Walz, U. (1997) "Innovation, Foreign Direct Investment and Growth", Economica, Vol. 64, No. 1, pp. 63-79.

Yang, C. H. and J. R. Chen (2001) "R\&D, Technology Imports and Patents-GMM on Count Panel Data", Taiwan Economic Review, Vol. 29, No. 1, pp. 69-87. 